\title{
SUSTAINABLE LIBRARY SERVICES BUILT ON OPEN \\ SOURCE SOFTWARE: A CASE STORY FROM KENYA
}

\author{
Unni Knutsen and Tor Arne Dahl, \\ Oslo University College Norway \\ with contributions from SIDAREC
}

\begin{abstract}
As part of a collaboration between the Kenyan organisation SIDAREC and Oslo University College we have provided Internet access and established a technological platform for a library situated in one of the poor areas in Nairobi. In our paper we share our experiences from implementing open source and web-based services in this community library. We also present some general views on how open source software and Internet technology may prove to be keys to creating modern, affordable and sustainable library services in developing countries.
\end{abstract}

\section{Résumé}

\section{Des services de bibliothèques durables fondés sur des logiciels Open Source: un cas pratique venu du Kenya}

Dans le cadre d'une collaboration entre l'organisation kényane SIDAREC et l'Université d'Oslo nous avons fourni un accès Internet et établit une plateforme technologique à une bibliothèque située dans l'un des quartiers les plus pauvres de Nairobi. Dans notre papier, nous partagerons notre expérience d'implantation d'un logiciel open source et des services Web dans cette bibliothèque communautaire. Nous ferons quelques réflexions générales sur la possibilité d'utiliser les logiciels open source et les technologies Internet comme des solutions clés pour créer des services de bibliothèques modernes, meilleur marché et durables dans les pays en developpement.

\section{Background}

Slums Information Development and Resource Centres (SIDAREC) is a local NGO which has been active in Nairobi since 1996. It is an empowerment project aiming at lifting young people in the poor areas of the Kenyan capital out of the conditions of poverty they are presently living in and enhancing their capabilities in managing and controlling their lives. The activities are divided into four main programmes: 
- Youth reproductive health (mainly preventative and promotive measures)

- Early childhood development (e.g. free pre-primary education, follow-ups, legal assistance)

- Entrepreneurship (helping to set up and sustain small business enterprises)

- Community media and ICT (e.g. library, computer training, cyber café, recording studio)

SIDAREC operates in two areas of Nairobi: Pumwani and Mukuru Kwa Njenga. In Mukuru Kwa Njenga they run a community clinic, a pharmacy and a pre-school. The Pumwani centre houses a studio, a community hall, a library and a nursery/preschool. All centres are managed by a Community Programme Officer (CPO) who is the overall in-charge of all programmes covered by the centre. The CPO is directly answerable to the project administrator who is the monitoring and evaluation person and in charge of personnel.

SIDAREC considers equal access to information as one of their major goals. Through building knowledge among the community members the NGO can enhance participatory development. As a consequence SIDAREC took the initiative to establish a library in Pumwani. The library was erected by the community and furnished by SIDAREC. The American organisation Books for Africa donated some 25000 books (approximately 6000 titles) which forms the collection.

The library staff lacked basic library training, and SIDAREC therefore approached the Kenya National Library Services (KNLS) for assistance. Kenya National Library Services is the national library of Kenya and also the leading public library. It was formed by an Act of Parliament in 1965 to develop public library services in the country. Over the years the KNLS Board has adopted a communitybased approach to establishing public libraries in all provinces. If communities put in place basic infrastructure, the Kenya National Library Services can provide initial book stock, staffing and meet recurrent expenditure. After discussions with Kenya National Library Services it was decided that SIDAREC was eligible for receiving small document donations, but could unfortunately not be helped in other ways.

As a consequence SIDAREC sent a message to an IFLA mailing list asking for technical assistance in developing a modern community library. Oslo University College responded to the call for assistance and initial discussions between the two institutions started in 2004. Both parties agreed that Oslo University College should send master students to Nairobi to work side by side with the youth. In 2005 Oslo University College visited the project and also the Kenya National Library Services to ascertain that the project would fit into Kenyan national library plans. In January 2006 the project co-ordinator, Lucy Mathai, visited Oslo University College to plan for the first phase of cooperation and secure funding. 


\section{Technology}

In 2005 SIDAREC Community Library was equipped with two stand-alone PCs. The library automated system ITS for Windows, developed by The Library Corporation (USA), was installed on one of the computers, and the staff had catalogued a small number of books. Copy-cataloguing was to a limited degree possible from CD-ROMs with a backlog of Library of Congress records. SIDAREC had acquired the cataloguing software for free for a trial period. Unfortunately, there had been a disk crash on the computer just before our involvement. Without backup tapes and backup routines, there was no way to restore the catalogue and the work done.

The library and SIDAREC's main office had dial-up connections to the Internet. SIDAREC also had a website with mainly static information about the organisation and its activities. The website was maintained by an Internet Service Provider/web hosting company in Nairobi. The SIDAREC staff did neither have the skills nor the necessary software to update their own website. If they wanted to publish new or update existing content, they had to pay the Internet Service Provider to do it for them.

None of the existing technologies described above seemed to fully satisfy SIDAREC's needs, so we had the previous experiences in mind when choosing technology.

The project had high ambitions for the outcome of the collaboration, but limited financial resources. Also, the library was scarcely equipped with computers and other hardware. Except for one person on a short-term contract, there were no librarians in the staff. Our challenge was therefore to identify affordable hardware and software that could easily be applied and maintained, and to give substantial training to the staff. However, the goal was not to turn the library staff into computer specialists. We therefore looked for low-cost maintenance solutions that could be transferred to local businesses or national institutions.

Our strategy in terms of cataloguing was to reuse bibliographic data from other sources. This seemed highly rational in terms of securing the quality of bibliographic data and improving and speeding up the process of cataloguing. Our approach is also in coherence with the concept of universal bibliographic control, where a bibliographic record is created in its country of origin - preferably by the national bibliographic agency - and reused by others.

\section{Internet connection}

One of SIDAREC's main concerns was the risk of its community members becoming further marginalised because of lack of computer skills and access to the infor- 
mation resources on the World Wide Web. Having fast and reliable access to the Internet was one of their basic conditions.

Our first task was therefore to consider how the library and the main office could connect to the Internet. The dial-up connections were slow, costly and unreliable, and certainly not suitable for efficient copy-cataloguing. Because of the costs, only members of staff were allowed to consult the Internet.

We explored several other options: WiMAX (Worldwide Interoperability for Microwave Access), satellite, cables or broadband wireless access. WiMAX is a very promising and affordable technology for developing countries without extensive wiring infrastructure, but there were no WiMAX distributors in Nairobi at that point in time. Based on the telecommunication infrastructure and costs of installation and subscription in Kenya, we chose a broadband wireless radio connection. At the time when the cooperation started there were no broadband Internet installations at all in the Pumwani area where the library is located. An 80 feet mast had to be erected as part of the installation - a true landmark!

\section{Website}

As a platform for web publishing, we had the choice between a stand-alone HTML editor or a content management system (CMS). An HTML editor is not a very scalable solution. The free and open source Flux CMS was therefore chosen. This CMS uses web standards from the World Wide Web Consortium and templates that are easily configurable for skilled users. Most importantly, it also has a WYSIWYG (What You See Is What You Get) editor for novice users without HTML skill. No other software than a standard web browser is needed to publish and update content on the website.

Rather than installing the software and manage it ourselves, we chose a hosting and maintenance service for the CMS and the website. SIDAREC currently has a subscription to Freeflux.net, a Swiss company that can provide these services for an annual fee of 77. In addition the Freeflux Pro account includes 200MB storage space and your own domain. The URL for the relaunched SIDAREC website is: http://sidarec.org/.

\section{Library automated system}

In coherence with our overall digital strategy in the project, a traditional card catalogue was not considered. We wanted a fully-fledged library automated system with functionality like acquisition/budget control, circulation, statistics and easy import 
of metadata. UNESCO's WEBLIS and CDS/ISIS library systems are free-of-charge and have many users in developing countries. From a financial point of view, this seemed to be a natural choice. However, based on evidence from other users, the system seemed to lack some of the functionalities we required.

The remaining options were commercial or open source web-based systems. Commercial vendors were discarded, because of potentially high initial and running costs and vendor 'lock-in'. The system SIDAREC had used so far, ITS for Windows, is an example of this. The software was offered for a free trial period, but eventually the software had to be paid for. In addition to the cataloguing module, an OPAC had to be purchased, possibly also a circulation module.

Because of its rich functionality, we chose Koha, an open source system that was first deployed in January 2000 at Horowhenua Library Trust, New Zealand. Many libraries around the world have later built their library services on Koha, most notably Nelsonville Public Library, USA, in 2003, with its seven branches. Nelsonville developed the functionality considerably and brought the source code back to the project. Koha is a modern library automated system that is flexible and highly configurable. Both the cataloguing module and the OPAC are web-based, which is not common in commercial systems. The Z39.50 module supports import of bibliographic records. Because our collection at the moment consists mainly of American books, we have based our cataloguing on metadata imported from the Library of Congress.

Koha is built on other open source products. The source code is written in Perl. It runs on an Apache web server and uses MySQL as a database. It can be installed on Microsoft Windows and Linux. Our implementation is on a Linux computer.

\section{Management}

One of SIDAREC's main goals was to transfer knowledge about how to run a library to the library staff. In addition to providing basic training skills in cataloguing, classification, the running of Koha and the library website, we also had thorough discussions with the library team and the community focus group about core values and administrative issues.

In order to identify the basic user groups, the most urgent needs and the general directions to take, the library staff and community focus group developed a strategic plan with the assistance of the first group of master students (spring 2006). This year (2007) a new group of master students and the library team have worked together to develop an acquisition plan. Resolutions in form of draft policies evolve from workshops and are passed on to the SIDAREC management team (comprising Director, Administrator, CPO and Finance Officer) for approval. The plans have, 
since they involve the Oslo University College, also been approved by the Oslo University College. In the future we are confident that all library policy papers will be developed by the volunteer team (focus group) and library staff without the support of Oslo University College.

The library is currently staffed with a qualified librarian and a team of young volunteers from the community who have been trained by Oslo University College. Though we have achieved many of the goals in our formal agreement of cooperation, we are still planning to work together to enhance the use of digital information resources within the community, create reading awareness and plan and implement further outreach activities.

The major challenges we are facing in terms of library management is how to secure sustainability in the longer perspective. SIDAREC is planning to introduce a small membership fee and also generate income through an Internet café. Hopefully in the long run local government will be able to take over or at least assist in running, the library. This is a situation we have seen in many countries in the past, Norway included.

\section{Collection and catalogue}

There is dire need to buy books with African content to supplement the existing collection. Funds have been secured through a grant from the surplus fund of the national organising committee of the IFLA World Library and Information Congress in Oslo 2005. As soon as the core collection has been recorded the purchase of local content will start. By mid May 2007 some 3000 books out of a total of 4800 remaining titles from Books for Africa have been catalogued in Koha. In addition, free Internet resources have been added to the library website.

So far we have concentrated on the cataloguing module in Koha. As soon as the core collection is catalogued the library will start lending material to its patrons. We will also start purchasing books with local or regional content and relevance. Within a relatively short time we will therefore start using the acquisition, members and circulation modules of Koha. We will also train one staff member as a system administrator.

Earlier this year we purchased a few Kenyan books to test the availability of national bibliographic records. Unfortunately the Kenya National Library Services is only partly computerized and does not provide any on-line service where bibliographic records can be downloaded. We found ourselves in a situation where we did not have the bibliographic services we required, but were forced to catalogue the books from scratch. We therefore approached the Library of Congress regional office in Nairobi and agreed that as soon as acquisition starts, we will send them lists 
of the material we have purchased. The regional office will then prioritize to catalogue the books that SIDAREC has collected. As can be expected, the Library of Congress acquisition policy does not match SIDAREC's, but this cooperation will still be helpful. It is, however, the responsibility of the Kenya National Library Services to offer on-line bibliographic data of the Kenyan national output and in our opinion this is a national issue that Kenya should urgently address.

\section{Technology}

The Koha server is currently located at the Oslo University College, where general maintenance, including backup and upgrading, is provided. We would like to move these operations to Kenya and are therefore currently exploring what our options are. These tasks require a certain level of computer skills, especially a general experience with open source software. As mentioned above, Koha is built on the widely used open source web server infrastructure called LAMP (Linux, Apache, MySQL, Perl), which means that there are many computer specialists who have acquired the skills to operate and maintain the software. There is a lot of documentation available on the web and an online community consisting of people all over the world who can help in case of trouble. However, we do not foresee that SIDAREC will have the necessary computer skills to run the system on their own server. We are therefore looking for a host that can update, upgrade and possibly adjust Koha to SIDAREC's specific needs.

Last year we learnt that Strathmore University Library in Nairobi is also a Koha user. Strathmore University is a private university specialising in commerce and information technology with some 4000 students and a total of 400 staff members. We visited the university early 2007 to share experiences and consider whether we could cooperate or enhance the use of Koha in Kenya. It turned out that several Kenyan libraries had contacted the university to have information on Koha, but that most were hesitant to start using it because they lacked the necessary ICT skills to fully operate it on their own. According to Bernard Shiundu, the university is considering offering ICT services to libraries interested in using Koha as their automated library system. Such a support system might in our opinion include setting up and installing the system, importing bibliographic data already created by the libraries in machine readable format into Koha, upgrading to future versions, adjusting the system to local requirements or even hosting the system on one of the Strathmore University's servers.

Such an approach would in our opinion be a wise step to take. Even though many Kenyan libraries are computerized, there would still be a considerable market for Koha. According to our knowledge, there is a substantial installed base of 
UNESCO's WEBLIS and CDS/ISIS in Kenya. For libraries using this software, there is a special migration guide at Koha's website.

If a general support structure could be set up, libraries with limited computer experiences would feel safe to choose Koha. By offering Koha to libraries which would be willing to pay the running costs involved, the level of automation would increase considerably. We think that establishing a low cost, modern, state-of-the art system such as Koha is an issue of utmost national importance. We would therefore suggest that the Kenya Library Association and the Kenya National Library Services consider promoting and facilitating this development. In the long run these libraries can form user communities and contribute to and participate in open source library projects such as Koha.

\section{Conclusions}

Internet technology has tremendously changed the daily life of citizens in high income countries during the last fifteen years. Internet users can access immense volumes of information unthinkable 20 years ago. Those without access to ICT in general and the Internet in the particular are falling behind and have disadvantages taking part in society. The gap between those who have access and those who haven't is commonly called the digital divide. This gap exists within industrialised countries, but the gap between developed and developing countries is much wider.

From our experiences, we will conclude that Internet access and open source software are the main keys to narrowing the digital divide. Nicholas Carr (2004) states that the advantages of investment in IT have been overrated. The advantages of early adopters - in this case libraries in high income level countries - will be lost when the technology becomes infrastructure and a commodity that anyone can use. This is important for developing countries. With relatively small investments in Internet access and open source software, libraries like SIDAREC Community Library can develop cutting-edge and competitive services that are available from any Internet access point. In many ways, a library starting from scratch - 'leapfrogging' straight to the web (Steinmueller 2001) - has advantages compared to a library with a legacy system that must be adjusted to the web.

With the initial zero cost of the open source software itself, the main considerations using open source software is the cost of management in a longer perspective. From our experiences, it seems challenging for small libraries to run their own Koha installations. In our opinion, the most efficient way to support and maintain the software installations is to establish user groups or communities on regional or national level. Open source software can also provide opportunities for local private companies. These companies can build a business model based on the support and 
maintenance services that libraries need. However, it is important for each library to maintain control of the software source code and the bibliographic records to prevent the 'lock-in' effect characterizing commercial vendors.

In open source software communities, the number of developers is small compared to the number of users. To keep the software competitive and up to date, continuing development is necessary. Today, Koha seems to have a very active community and patches and new versions are released frequently. However, when new countries are starting to use the software, they will probably find local needs that haven't been addressed in the software. In Kenya, for instance, a Kiswahili translation is needed since Kiswahili and English are both official languages. It is our hope that African users can collaborate on translation projects, and in the long run also take part in the development of the software to keep Koha alive. Any such effort must of course be brought back to the Koha project to make the new features available to other users.

Economic constraints are hampering library automation in Africa. This creates a situation where distribution of bibliographic records is not effective. To prevent duplication of cataloguing work, the national libraries must provide bibliographic records on the Internet as a source for copy-cataloguing, both within the countries and worldwide in accordance with the principle of universal bibliographic control. To improve the level of automation within a country or region, Koha could be a very useful tool.

\section{Reference}

Carr, N. G. (2004). Does IT matter? Information technology and the corrosion of competitive advantage. Boston, Mass.: Harvard Business School Press

Steinmueller, W. E. (2001). ICTs and the possibilities for leapfrogging by developing countries. International Labour Review, 140 (2), 193-210 